UDC 338.24.01:615

JEL Classification: I10, I19, M31

http://doi.org/10.21272/mmi.2018.4-10

Robert Stefko,

Ph.D., Professor, University of Presov, Slovak Republic

Frantisek Pollak,

Ph.D., Professor, University of Presov, Slovak Republic

Beata Gavurova,

Ph.D., Associate Professor, Technical University of Kosice, Slovak Republic

\title{
OFFLINE AND ONLINE APPROACHES TO QUALITY PERCEPTION OF SLOVAK UNIVERSITY HOSPITALS
}

\begin{abstract}
The aim of this paper is to present selected offline and online approaches to the issue of customers quality perception, more specifically the methods of its measurements across the markets, both offline and online in the field of health care providers operating in the Central European market. With the utilization of methodology of simplified online reputation analysis aimed specific environment of healthcare providers, represented by the whole file of relevant subjects, all the Slovak university hospitals, significant relationships between factors were examined in order to identify and describe facts affecting online reputation of those entities in the hyper-competitive market environment of the Internet. We consider it necessary to examine the correlation between the determinants of perceived quality. Partial scores of entities from individual rankings were statistically tested in order to determine whether on the chosen significance level there is a statistically significant correlation between scores of entities achieved with various determinants and score achieved through a simplified version of advanced sentiment analysis. Last but not least variables such as the score achieved through the simplified version of advanced sentiment analysis and the absolute number of pages indexed by Google containing a generally used the name of an entity as the keyword were statistically tested. The findings identified by the analysis of the online environment were compared to up to date traditional ratings from the traditional offline world. In conclusion of the presented paper, the results of analysis providing a comprehensive view of the issue of selected approaches to quality perception in the widest and most actual possible range of perspectives. The presented methodology also represents a comprehensive tool for analyzing a quality perception for a wide range of subjects trying to maximize their market advantages, often by using enormous marketing effort, against their competitors.
\end{abstract}

Keywords: quality, healthcare, hospital, customer, competition, marketing, Slovak.

Introduction. In our lives, there are just a few things, if any, on which we depend more than on health, especially when we are not in a good health condition. When we have some health issues, we are looking for the right place where we will receive the best care. In the brick world, it is quite simple, there are plenty of official or semi-official rankings, which define the market of health care providers. Factors which affect rankings are well known, and best players learned how to set their processes to achieve the best score. Market conditions are changing, we are living in the world when the internet becomes the main information source. We looking for information by googling, so the question is, how the best players on the market handling their virtual reputation. As we stated above, in the brick world, there are certain steps, which need to be followed. Physical evidence in the meaning of equipment, interior and exterior of buildings, and, of course, the willingness and expertise of the staff. Those factors are crucial for getting a good rating. All of those factors are costly to maintain and operate. The virtual world is different if your first and often the last one experience from the specific subject is by his online presence, the situation regarding the development of positive presence is changing dramatically. Based on our previous research (Pollák, Belovodská, 2015) we can say, that the larger the subject is, the more difficult is to maintain its online reputation. This situation is pretty the same in the whole region. Classical marketing approaches are failing and new are under development. The relatively open character of the internet creates space for spreading half-truths,

Cite as: Stefko, R., Pollak, F., \& Gavurova, B. (2018). Offline and Online Approaches to Quality Perception of Slovak University Hospitals. Marketing and Management of Innovations, 4, 107-115. http://doi.org/10.21272/mmi.2018.4-10 
slandering and lies. Since on internet, there is almost impossible to control the context of countless quantities of sources, even small and objectively weak organizations can pose Big, shiny and strong. This unequal struggle can only be won by understanding the factors influencing the new market of internet presence and competitive fight on the basis of subjective factors. The quality perception is an extremely important factor for gaining and strengthening consumer trust and confidence in the virtual as well as real world (Helm, et al., 2011, Gottschalk, 2011, Pollák, et al. 2016). Trust building is a long and arduous process and includes feelings, impressions and experiences of people who came into contact with the given company/business entity. Business entities pay this matter due attention. (Kanel, 2013) Its importance is undeniably gaining momentum, especially in the current period when an image, long-lasting dominant position on the market and a huge success are not possible only thanks to innovative know-how and unique products, determination, undying entrepreneurial spirit, flexibility and capability in the particular field of business (Litavcová, Bucki, Štefko 2015). The vision of a successful business needs a bit more than just that (Balmer and Greyser, 2003). An issue of positive quality perception, as well as an issue of the effective utilization of tools for quality management, is becoming one of hottest topics in marketing management without difference regarding specific fields (Štefko, Jenčová, Litavcová, 2017). According to surveys carried out by foreign research agencies, when faced with a choice between two products with comparable properties, $89 \%$ of consumers ultimately decided on the basis of the popularity of the brand and its perceived quality. Moreover, $72 \%$ of them added that the company's image influences their purchasing decisions and investments to the great extent (Pollák, 2015).

Literature review. Many authors (Kanika, 2016, Sasko, 2014, Pollák and Belovodská, 2015) argue that the concept of building a positive image in the internet environment may cover many aspects ranging from the organic presence in the search results, through traditional channels of marketing communication to its presence in its own virtual channels via social media. Perceived Image is thus the result of the activities carried out by a business entity on the Internet. The complex image also includes interaction with customers and their reactions (Fill, 2009). Today, there is no need to question why the online environment is important, but rather how to analyze the current state of the online environment and how to get started with active communication management (Marsden, 2013). In the following three points, we will point out a few facts that are crucial for active online branding:

- the number of potential online customers is increasing;

- availability of information on the Internet;

- need to keep the brand/ image under control.

It is an objective fact that the number of potential online customers is increasing. More and more organizations are becoming aware of the fact that online presence is a necessity. Consumers enjoy fast access to and favourable prices of services and goods on the Internet. It is likely that people soon will buy online goods and services mainly because of their convenience and not only for favourable prices. Therefore, online presence and perceived image are crucial for attracting new customers (Štefko, Bačík, Fedorko, 2014, Štefko, Fedorko, Bačík, 2015) Online references and reviews have a similar effect as recommendations from customers. Overlooking online presence may mean the difference between success and failure or bankruptcy (Leboff, 2011). Another very important factor speaking in favour of online presence is the ever-increasing availability of information. Nowadays many people are familiar with social networks which also feature online reviews. It is quite possible that a lot of things we do offline will become online matters. Therefore, it is important to remember that the online and offline world are closely linked and our business activities in the offline world will be eventually reflected in our online image (Marsden, 2013). Online quality management is one of the best possible ways to find out the current status of the business entity's corporate brand (Štefko, Pollák 2016). It is more than possible that our customers will at some point of time leave a review on the Internet (Štefko, Fedorko, Bačik, et al., 2015, Štefko, Fedorko, Bačík 2016). In addition to web platforms and websites, it is necessary to control all the "other" media 
associated with our brands like the interaction with customers, fans or even competitors (Pollák, 2015). The article provides an insight into the active quality management in the online environment using a thorough analysis of one of the available methodologies. Moreover, the article also evaluates data, identifies common background and provides recommendations regarding the subject matter, namely university hospitals operating on the Slovak market.

Aims and methods. The main objective of the paper is to present complex approach for measuring customers quality perception, more specifically the methods of its measurements across the markets (both brick and virtual) in the field of health care providers operating in the selected Central European market with an aim to increase their competitiveness through a better understanding of the basic determinants of effective marketing management of health care providers and thus selected perspectives of marketing management in general. Since the factors affecting the reputation across the various markets within the geographical units are relatively the same (given the topicality of the issue and the relative novelty of the problem) conditions that must be enforced in virtual environments, we evaluate the research object as relevant to meet the research goal. Based on the current state of the issue theoretical knowledge and bases were accumulated, that provide the knowledge base for the subsequent empirical research.

A thorough simplified multifactor analysis of reputation in the virtual world of the Internet was conducted on a specific sample of entities, all the 11 Slovak university hospitals (by the legal form, they are a contributive organization), primary compared to up to date ranking of the main player on selected market:

- to the General Health Insurance Company (in the table indicate in \% as VsZP score),

- to the non-profit organization INEKO 2016 ranking,

- and to the ring by health insurance company Dôvera 2016.

For the purpose of this research, we used modified (a for this research issue simplified) multi-factor sentiment analysis on which we would like to demonstrate model option for measuring total online reputation (TOR) of selected entities as a complex indicator for perceived customer quality/ value of the selected subjects. The methodology of the modified multi-factor analysis of the total online reputation TOR described by Pollák et al. (2016), brings more variability in its application on a broader spectrum of subjects than standard multi-factor analysis introduced by Sasko (2014). Moreover, it also brings a comprehensive look at the perceived image of the given entity relative to the total possible perceived image expressed as a percentage. The methodology used in the TOR index uses $n$-factors.

For each of analyzed subject, the first step analyses the sentiment of the first 10 results on Google. The cleanliness of the results is secured by anonymous proxy as well as the private mode in the chosen internet browser. Also, only the organic results of searching are taken into consideration.

From the point of view of methodology, at least two sets of measurement are required. The standard is to test the 1st group: name of the entity, 2nd group: adding another keyword to or repeat the measurement with one parameter, this time in the Google tab "News". It should be pointed out that in terms of the dynamics of published reports this was the least stable parameter. In any case, the number of groups is not particularly limited. Quantification is then ensured by unifying the scores into the percentage form. This is based on the assumption that within a single group the entity may receive a maximum score of 155 points - the ratio 1 point $=0.645 \%$. For purpose of our analysis with 2 groups, the entity may receive a maximum score of 310 points - the ratio 1 point $=0.32 \%$.

The second step identifies the determinants of online reputation, the reputators.

Reputator can be any determinant that can objectively affect the perceived online reputation of the entity, while its value can be quantified as a percentage. Normally these are important web pages, catalogues or social networks that can significantly affect the reputation of the entity. Given the various business fields entities operate in, reputation determinants cannot be clearly defined in advance. In terms of the presented research study, we consider to present methodology in its purest form, so we did not 
include additional reputators into the calculation.

In the third step, we can calculate the total perceived image of the entity's online presence with regard to its pre-defined competitors, as follows: Standard equation Pollák, et al. (2016) features specific determinants of perceived online presence and their weight. The basic reputation determinant is the ASA percentage score. The equation allows us to take into account any number of other reputation determinants. For the calculation itself, it is necessary to determine the weights of individual reputation determinants which are normally determined depending on the subject and target market. If the weight of individual reputation determinants is not known in advance, the simplified formula for calculating the overall online reputation is as follows:

$$
T O R=\frac{R_{A S A}+\sum_{i=1}^{n} R_{i}}{n+1}
$$

where TOR - total online reputation $\vee \% ; R_{i}$ - reputation determinant (\% score according to the particular $i$ - reputation determinant); $R_{A S A}-$ ASA reputation determinant (\%score according to the advanced sentiment analysis); $n$ - the number of determinants

In this case (simplified calculating scenario), the value of the overall online reputation is equal to ASA reputation determinant. Relationships between online and offline factors were examined in order to identify and describe facts affecting the online perceived quality of those health care providers in the hypercompetitive market environment of the Internet.

Results. With regard to the patient's choice of healthcare facilities as well as the availability of health care providers in the home and neighboring markets (not to mention the mutual rivalry between healthcare providers), each of the set of selected entities, in this case all the 11 Slovak university hospitals try to shape their reputation both within real and virtual world through their management. For the purposes of our research, we focused on the virtual world of the Internet. Overview table of the partial score of perceived quality of Healthcare Providers.

Table 1 - Overall (Total) perceived online image

\begin{tabular}{|c|l|c|c|c|c|c|c|}
\hline $\begin{array}{c}\text { Rank } \\
\text { by } \\
\text { VsZP }\end{array}$ & \multicolumn{1}{|c|}{ Subject/ Result sentiment } & $\begin{array}{c}\text { ASA } \\
\text { score } \\
(\%)\end{array}$ & $\begin{array}{c}\text { No. of } \\
\text { pages } \\
\text { indexed } \\
\text { by } \\
\text { Google }\end{array}$ & $\begin{array}{c}\text { INEKO } \\
\text { rating } \\
(\%)\end{array}$ & $\begin{array}{c}\text { Dôvera } \\
\text { Rank } \\
2016\end{array}$ & $\begin{array}{c}\text { VsZP } \\
\text { score } \\
(\%)\end{array}$ & $\begin{array}{c}\text { TOR } \\
\text { score } \\
(\%)\end{array}$ \\
\hline 1 & University Hospital Martin & 70.40 & 67,000 & 52.40 & 2 & 71.16 & 70.40 \\
\hline 2 & Central Military Hospital SNP Ruzomberok & 50.56 & 25,200 & 55.10 & 1 & 69.11 & 50.56 \\
\hline 3 & Faculty Hospital Nitra & 11.84 & 77,200 & 60.10 & 9 & 68.92 & 11.84 \\
\hline 4 & University Hospital of L. Pasteur Kosice & 51.52 & 160,000 & 30.30 & 6 & 66.49 & 51.52 \\
\hline 5 & $\begin{array}{l}\text { Faculty Hospital F.D. Roosevelt Banskán } \\
\text { Bystrica }\end{array}$ & 57.92 & 27,400 & 56.00 & 4 & 64.27 & 57.92 \\
\hline 6 & Faculty Hospital Nove Zamky & 31.36 & 30,300 & 47.50 & 8 & 61.69 & 31.36 \\
\hline 7 & Faculty Hospital Trencin & 47.36 & 62,700 & 42.20 & 5 & 59.74 & 47.36 \\
\hline 8 & University Hospital Bratislava & 37.76 & 157,000 & 35.30 & 10 & 58.06 & 37.76 \\
\hline 9 & Faculty Hospital Zilina & 32.64 & 61,000 & 23.20 & 3 & 57.19 & 32.64 \\
\hline 10 & Faculty Hospital J.A.Reimana Presov & 36.80 & 22,700 & 42.70 & 7 & 57.16 & 36.80 \\
\hline 11 & Faculty Hospital Trnava & 26.88 & 58,700 & 35.40 & 11 & 55.54 & 26.88 \\
\hline
\end{tabular}

Sources: own processing 
Using the advanced sentiment analysis (ASA), we calculated the partial score presenting the power of the perceived online image of entities based on the nature of the first 10 Google search results. Google and its search results are, however, only one of many ways in which potential customers can access relevant information.

Before we analyze the results by statistical testing, it is necessary to expand the specific values and partial score for the analyzed subjects through the overview table. The following table presents partial results - the perceived quality of selected subject across brick and the virtual market, as well as the score of the total (overall), perceived online image. The following figure points out some interesting outcomes of the analysis:

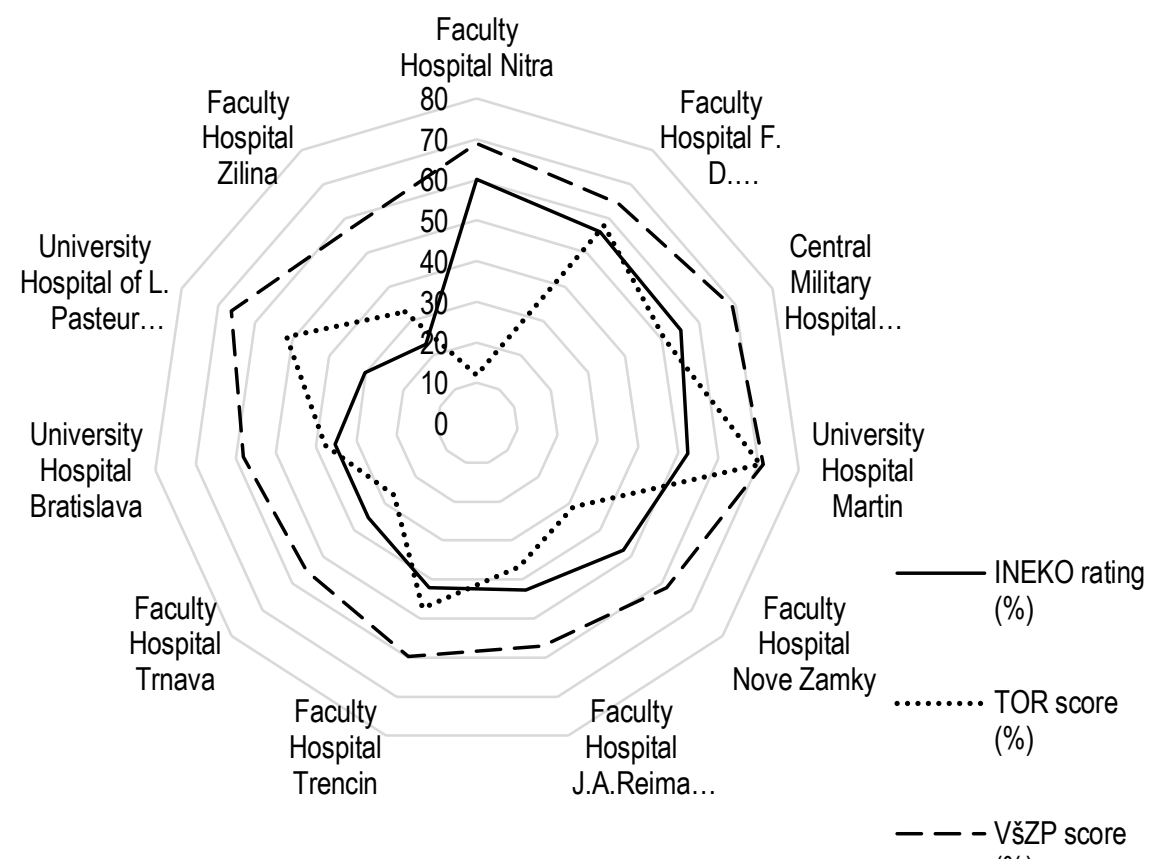

$(\%)$

Figure 1 - Traditional rankings vs. Overall perceived online image

Sources: own processing

In comparison with the results of the VsZP, the score of the analyzed subjects with regard to their online presence was slightly different, for example, the University Hospital in Nitra has recorded a decline in their online perceived presence when compared to results of VsZP by more than $50 \%$.

Analysis of the relationship between the determinants of perceived quality. We consider it necessary to examine the correlation between determinants of perceived quality, more precisely the correlation between those selected determinants, which we considered (based on our previous researches) important. Partial scores of entities from individual rankings were statistically tested in order to determine whether on the chosen significance level there is a statistically significant correlation between scores of entities achieved with various determinants and score achieved through advanced sentiment 
analysis. Last but not least variables such as the score achieved through the advanced sentiment analysis and the absolute number of pages indexed by Google containing a generally used the name of an entity as the keyword were statistically tested.

Table 2 - Link between ASA and selected ratings

\begin{tabular}{|l|c|c|c|c|}
\hline \multirow{2}{*}{ Variables } & \multicolumn{4}{|c|}{ Kendall Tau. Level of significance: $\mathbf{p}<\mathbf{0 . 0 5}$} \\
\cline { 2 - 5 } & No. & Kendall tau & $\mathrm{Z}$ & $\mathrm{p}$-value \\
\hline ASA \& Dovera & 11 & 0.527273 & 2.257647 & 0.023968 \\
\hline ASA \& VsZP & 11 & 0.418182 & 1.790548 & 0.073366 \\
\hline ASA \& Google index & 11 & 0.054545 & 0.233550 & 0.815335 \\
\hline
\end{tabular}

Sources: own processing

Discussion. As we stated above, and as can be seen in Table No. 1, we focused on analyzing the perceived quality of the selected subject using advanced sentiment analysis. For each analyzed subject, we took into account the first ten results after typing in the selected keywords - the name of the university hospital - in the search engine Google.

The first results featured, as expected, hospitals own websites. This came out as not surprising fact since the situation is almost the same for all sectors of business. It was expected that the following nine search results will be of a neutral character, however, this was confirmed only in two cases - university hospitals in Presov and Kosice. Neutral search results are mostly various sub-pages of the homepage or various formal references found on pages related to the subject. Although they do not damage the reputation of the subject, they definitely do not add to its value with respect to the virtual "attractiveness".

Positive search results related to the searched subject are from the point of view of the perceived quality of Internet users more interesting, especially if users have no direct experience with any of those. The perception of the subject is thus established on very subjective - virtual experience. In this case, the positive sentiment regarding the studied subject was generally associated with the presence of the subject on Wikipedia or its profile on Facebook or other social media showing up in the first ten search results. Reviews of the studied subject appearing in the first ten search results after typing in the name of the studied subject were also considered as positive sentiment. An interesting finding highlighting the pitfalls of neutral reputation is a situation where the previously mentioned university hospitals in Presov and Kosice (both reaching in the first measurement of one parameter almost $30 \%$ of the total possible reputation) achieved a score only slightly higher than the University Hospital of Nitra (the winner of the evaluation carried out by the Institute INEKO), which recorded a significant negative sentiment in three out of ten Google search results. However, it compensated this loss by achieving three positive sentiments on positions 2, 4 and 8. Neutral sentiments can be easily removed and replaced with negative sentiments. The absence of positive sentiment can get any subject to red numbers.

Then we repeated the measurements using only one parameter, the full name of the subject. We focused on the results found in the tab "News". Based on the results we can state that the subjects are relatively good in mastering media communication. Except for three cases, namely University Hospital Nitra, Trnava and Bratislava, the subjects have not recorded more than one negative sentiment - negative reporting in the first 10 search results. However, there was no clear winner. The first place is held by the University Hospital in Kosice and the University Hospital in Martin, who achieved almost the maximum level of the positive perceived image. It should be pointed out that we made a methodological adjustment in the case of the Faculty Hospital in Martin since "Martin" is also a very popular male name. Therefore, we had to search the results for this hospital using quotes, which indeed might (but did not have to) affected the accuracy of the search results.

Regarding the link between scores of entities achieved through different measurements and scores 
achieved through advanced sentiment analysis, statistical testing presented in Table No.2 almost in all cases (two of three) did not confirm any link between variables on the significance level we selected. On the basis of the analysis, we were able to proceed with the statistical analysis of the selected context. Regarding the correlation between Dôvera rank and the level of ASA, at the chosen significance level of $5 \%$, the $p$-value is lower than 0.05 . We have therefore cannot refuse the existence of the statistically significant correlation between those two variables.

Regarding the absolute number of pages indexed by Google which include the usual name of the given entity as a keyword does not have any statistically significant impact on the level of online perceived presence represented by ASA score of that entity. The proven argument for the necessity of quality over quantity applies here as well.

Conclusion. From the point of view of analyzed subjects, hospitals in the leading positions have a distinct advantage in terms of their perceived quality among Internet users. In case the user seeking information about a particular subject does not encounter positive image indicators, this can ultimately affect his/ her overall perception of the entity. This is especially true if customers/ patients are users who have not personally visited the subject yet and they make their opinions solely on the basis of information present in the online environment. Hospitals should attempt to curb negative publicity, and vice versa, to enhance and work on positive publicity. This can be achieved particularly through the active online communication policy like dissemination of positive information through renowned major online newspapers or social networks. The best way to remove negative or neutral publicity in the first ten search results is a lateral displacement of negative publicity by a thoughtful marketing communication policy conducted in the online environment. In general, it would seem that the most effective model of comprehensive online quality management is to focus on dominant perceived quality determinants, namely Google search results. As indicated above, active instruments of the online quality management can greatly facilitate active communication with the public, help in acquiring and evaluating feedback or speed up implementation of measures related to a crisis marketing communication. Without a strong base of users, none of this is possible, not with a significant result. Anyhow, the comprehensive analysis provided comprehensive results, however, it is necessary to point out the limitations of our research, particularly data availability at the time the research was conducted. We would like to state that the resulting comparisons and formulated interpretations provide a realistic, up to date and comprehensive view of the market of health care providers focusing on the university hospitals. The offline world represented by traditional players largely affects the reputation of selected entities, especially among professionals. Given the specificities of the time (and the number of other research and analyses) we would like to state that the general public is affected by those traditional players in terms of perceive of quality of particular provider shaping to a limited extent. The centre of the information world is the Internet. Another trend of the times, the move away from mainstream information sources to alternative media and community portals makes the process of quality management and active marketing communication harder to control. The strength of that person's "marketing" message appeared in the online environment is enforced through authenticity that this message carries and making it look legit. Since the factors affecting the reputation across the various markets within the geographical units are relatively the same (given the topicality of the issue and the relative novelty of the problem) conditions that must be enforced in virtual environments, we evaluate the research object as relevant to meet the research goal. Our research synthesizes all mentioned viewpoints and offers a clear comparison of the perceived quality of analyzed subjects across both worlds (online and offline). The results (processed graphically) bring interesting findings worthy of greater consideration.

Funding. This research study is one of the outputs from the research grant VEGA No: 1/0945/17, entitled: "Economic research on quantity. of marketing processes improving values for patients, 
multidimen. analysis of the mark. mix of HCF and quantif. of their importance in the process of establis. a system to measure the quality and efficiency of the Slovak HHC".

\section{References}

Balmer, J., \& Greyser, S. (2003), Revealing the Corporation: Perspectives on Identity, Image, Reputation, Corporate Branding and Corporate-level Marketing. Oxford: Routledge.

Dôvera. (2016). Hodnotenie nemocníc podla pacientov 2016. Retrieved from https://www.dovera.sk/hodnotenie/2016/celkovehodnotenie. (Slovak)

Fill, C. (2009). Marketing Communications: Interactivity, Communities and Content. 5th Edition. UK: Pearson Education Ltd.

Gottschalk, P. (2011). Corporate Social Responsibility, Fovernance and Corporate Reputation. USA: World Scientific Publishing Co. Pte. Ltd.

Helm, S., et al. (2011). Reputation Management. Berlin: Springer-Verlag.

Ineko. (2016). Hospital of the year 2016. Retrieved from http://nemocnice.ineko.sk/ nemocnica_roka/2016/

Kaenel, A., Ch., von. (2013). Vertrauen bei Online-Transaktionen - Vertrauenstypen im Online-Entscheidungsfindungsprozess. Dissertation Nr. 4190. Der Universität St.Gallen, Hochschule für Wirtschafts, Rechts und Sozialwissenschaften sowie Internationale Beziehungen (HSG). Retrieved from http://verdi.unisg.ch/www/edis.nsf/SysLkpByldentifier/4190/\$FILE/dis4190.pdf

Kanika, D. (2016). Prečo je online reputácia dôležitá? Retrieved from http://www.pranswer.com/sk/manazment-povestireferencie-a-recenzie/preco-je-online-reputacia-dolezita/ (Slovak)

Leboff, G. (2011). Sticky marketing - Jak zaujmout, získat a udržtet si zákazníky. Prague: Management Press. (Czech)

Litavcová, E., Bucki, R., Štefko, R. (2015). Consumer's behaviour in east Slovakia after euro introduction during the crisis. Prague economic papers, (24)3, pp. 332-353.

Marsden, H. (2013). Guard Your Reputation On-line. Birmingham: Smartebookshop.

Pollák, F. (2015). On-line reputačný manažment v podmienkach stredoeurópskeho virtuálneho trhu. Prešov: Bookman. (Slovak) Pollák, F., \& Belovodská, K. (2015). Multifactor analysis of online reputation as a tool for enhancing competitiveness of selected health care providers, In Annual international conference on enterprise marketing and globalization, Global science and technology forum, Singapore, pp. 6-12.

Pollák, F., et al. (2016). Sustainable E-marketing of Selected Tourism Subjects from the Mediterranean Through Active Online Reputation Management. In Volume 166 of the series Lecture Notes of the Institute for Computer Sciences, Social Informatics and Telecommunications Engineering, Toronto: Springer, pp. 692-703.

Sasko, J. (2014) Dbáte na hodnotu svojej značky? Retrieved from http://www.podnikajte.sk/manazmentmarketing/c/1392/ category/ marketing/article /online-reputacny-manazment.xhtml (Slovak)

Štefko, R., Fedorko, R., Bačík, R. (2016). Website content quality in terms of perceived image of higer education institution. Polish Journal of Management Studies, (13)2, pp. 153-163.

Štefko, R., Fedorko, R., Bačik, R., 2015. The Role of E-marketing Tools in Constructing the Image of a Higher Education Institution. In: Procedia: social \& behavioral sciences. Proceedings of the 3rd International Conference on Strategic Innovative Marketing (IC-SIM), Location: Madrid, Spain. Vol. 175, p. 431-438. ISSN 1877-0428.

Štefko, R., Bačik, R., Fedorko, I., 2014. Facebook Content Analysis of Banks Operating on Slovak Market. In: Polish Journal of Management Studies. Vol. 10(1), p. 145-152. ISSN 2081-7452.

Štefko, R., Fedorko, I., Bačik, R., et al. 2015. An Analysis of Perceived Topicality of Website Content Influence in Terms of Reputation Management. In: Polish Journal of Management Studies. Vol. 12(1), p. 177-185. ISSN 2081-7452.

Štefko, R., Jencova, S., Litavcova, E. (2017). Management and funding of the healthcare system. Polish Journal of Management Studies, (16)2, pp. 266-277.

Štefko, R., Pollak, F. (2016), Multifactor analysis of online reputation as a tool for enhancing competitiveness of selected Slovak towns. European journal of science and theology. (12)5. pp. 195-204.

VšZP. (2016). prieskum spokojnosti pacientov 2016. Retrieved from https://www.vszp.sk/poskytovatelia/indikatorykvality/prieskum-spokojnosti-pacientov-2016/. (Slovak)

P. Стефко, Ph.D., професор, Прешовський університет (Словаччина);

Ф. Поллак, Ph.D., професор, Прешовський університет (Словаччина);

Б. Гавурова, Ph.D., доцент, Технічний університет в Кошице (Словаччина).

Офлайн та онлайн підходи до оцінки сприйняття споживачами якості послуг словацьких університетських клінік

Метою даної статтіє аналіз офлайнових і онлайнових підходів до оцінки сприйняття споживачами якості наданих послуг у сфері медичних послуг на центральноєвропейському ринку. У статті автори використовували методологію спрощеного онлайн аналізу репутації, спрямованої на конкретних постачальників послуг у сфері охорони здоров'я. Об'єктом дослідження були споживачі послуг університетських клінік Словаччини. Так, результати дослідження підтвердили гіпотезу наявності статистично значимого взаємозв'язку між аналізованими факторами, що впливають на репутацію на висококонкурентному 
онлайн ринку. У рамках дослідження автори перевіряли гіпотезу щодо наявності кореляції між детермінантами, що формують відношення клієнтів до якості наданих послуг. Емпіричні результати аналізу інтенсивності подій підтвердили статистичну значимість взаємозв'язку між досліджуваними детермінантами та індивідуальним рейтингом постачальника послуг у сфері охорони здоров'я. У якості змінних параметрів аналізувались оцінка, отримана у ході спрощеного аналізу інтенсивності подій, та абсолютна кількість сторінок, проіндексованих Google, що містять загальновживане ім'я об'єкту як ключове слово. Результати дослідження були порівняні з наявними рейтингами в Інтернет-просторі. У статті автори наголошують, що отримані результати дають підстави сформувати комплексний підхід до оцінки сприйняття якості споживачами послуг у сфері охорони здоров'я. Запропонована методологія є комплексним інструментом аналізу сприйняття споживачами якості медичних послуг, що враховує ринкові переваги постачальника послуг, що в свою чергу є альтернативою традиційних дороговартісних маркетингових досліджень. Окрім цього дана методологія може бути застосована та апробована для інших галузей з метою виявлення та максимізації конкурентних переваг на глобальному онлайн ринку.

Ключові слова: якість, охорона здоров'я, лікарня, клієнт, конкуренція, маркетинг.

Manuscript received: 28.10 .2018

(C) The author(s) 2018. This article is published with open access at Sumy State University. 